\title{
Land use determinants of small mammal abundance and distribution in a plague endemic area of Lushoto District, Tanzania
}

PROCHES HIERONIMO ${ }^{*}$, DIDAS N. KIMARO ${ }^{1}$, NGANGA I. KIHUPI ${ }^{1}$, HUBERT GULINCK ${ }^{2}$, LOTH S. MULUNGU ${ }^{3}$, BALTHAZAR M. MSANYA ${ }^{4}$, HERWIG LEIRS ${ }^{5}$ and JOZEF A. DECKERS ${ }^{2}$

${ }^{1}$ Department of Agricultural Engineering and Land Planning, Sokoine University of Agriculture, P.0. Box 3003, Morogoro, Tanzania

${ }^{2}$ Department of Earth and Environmental Sciences, University of Leuven, Celestijnenlaan 200E, Leuven, Belgium

${ }^{3}$ Pest Management Centre, Sokoine University of Agriculture, P.O. Box 3110, Morogoro, Tanzania

${ }^{4}$ Department of Soil Science, Sokoine University of Agriculture, P.O. Box 3008, Morogoro, Tanzania

${ }^{5}$ Evolutionary Ecology Group, Universiteit Antwerpen, Groenenborgerlaan 171, B-2020 Antwerpen, Belgium

\begin{abstract}
Small mammals are considered to be involved in the transmission cycle of bubonic plague, still occurring in different parts of the world, including the Lushoto District in Tanzania. The objective of this study was to determine the relationship between land use types and practices and small mammal abundance and distribution. A field survey was used to collect data in three landscapes differing in plague incidences. Data collection was done both in the wet season (April-June 2012) and dry season (AugustOctober 2012). Analysis of variance and Boosted Regression Trees (BRT) modelling technique were used to establish the relationship between land use and small mammal abundance and distribution. Significant variations $(p \leq 0.05)$ of small mammal abundance among land use types were identified. Plantation forest with farming, natural forest and fallow had higher populations of small mammals than the other aggregated land use types. The influence of individual land use types on small mammal abundance level showed that, in both dry and wet seasons, miraba and fallow tended to favour small mammals' habitation whereas land tillage practices had the opposite effect. In addition, during the wet season crop types such as potato and maize appeared to positively influence the distribution and abundance of small mammals which was attributed to both shelter and food availability. Based on the findings from this study it is recommended that future efforts to predict and map spatial and temporal human plague infection risk at fine scale should consider the role played by land use and associated human activities on small mammal abundance and distribution.
\end{abstract}

Keywords: land use, small mammals, abundance, distribution, plague, infection risk, Tanzania

\section{Introduction}

Land use determines the spatial distribution of vectors and hosts according to their food and habitat preference (Linard et al., 2007). Like other animals, small mammals must obtain sufficient energy, nutrients and vitamins and escape predators to survive and reproduce. Their patterns of distribution may thus be influenced by the distribution and abundance of habitat resources. The most critical factors that have been found to influence small mammal distribution are thought to be food and shelter (Cooney et al., 1982). Total rodent abundance has been found to increase with increasing shrub cover in Kalahari in Namibia (Blaum et al., 2007) and the Kibale Mountains of Uganda (Isabirye-Basuta \& Kasenene, 1987). In the West Usambara Mountains of northeastern Tanzania, the abundance of some rodent species has been shown to increase with food availability (Makundi et al., 2007; Mulungu et al., 2011).

Small mammals have been associated with plague in West Usambara Mountains, Tanzania (Kilonzo \& Mhina, 1982; Mulungu et al., 2010). It is known that irregular epizootics are a common feature of sylvatic plague (Gage \& Kosoy, 2005) and such dynamics in the wildlife host populations in the Usambara Mountains provide the most likely explanation for the high degree of temporal variation in human plague cases. That is, years in which there are outbreaks of human plague are those that plague epizootics occur in the wildlife and peridomestic rodent communities (Davis et al., 2006). Therefore, increasing densities of rodents in the West Usambara

\footnotetext{
* Correspondence: Proches Hieronimo; E-mail: phmusigula@gmail.com
} 
Mountains is likely to increase the risk of plague outbreaks in humans (Kilonzo et al., 2005; Makundi et al., 2007, 2008).

Various studies on the role of rodents in rodent-borne zoonoses transmission cycles have been conducted in the West Usambara Mountains and elsewhere in Tanzania (Kilonzo \& Mhina, 1982; Kilozo et al., 2005; Makundi et al., 2003, 2008; Laudisoit et al., 2009a; Mulungu et al., 2010, 2011). These studies have demonstrated the role of shelter and food preferences of small mammals. However, the studies could not document the specific land use types and land management practices associated with small mammal distribution and abundance at a fine scale and within a wider geographic coverage which is important for delineation of potential risk areas (Eisen et al., 2012).

Since, some rodent species have been reported to play a dynamic role in the plague transmission cycle and the fact that these rodents are hosts of fleas (plague vectors) it is important to study their association with various land use types. This will contribute to an understanding of how to device ways and means to implement ecologically-based rodent management strategies focussing on specific land use types and land management practices which is currently lacking. The objective of this study was therefore to determine the relationship between land use types and practices and small mammal abundance and distribution in the West Usambara Mountains in Tanzania. Although, the role of individual species of small mammals and fleas in persistence and transmission of bubonic plague is not well known, gaining more insight in the relationship between land use and small mammals in general is certainly an important step towards an understanding of the plague system in a specific area.

\section{Materials and Methods}

\section{Study area}

The study was conducted in West Usambara Mountains, Lushoto District, Tanzania, in an area selected between Universal Transverse Mercator (UTM) coordinates $400000 \mathrm{~m} \mathrm{E}$ and $430000 \mathrm{~m}$ $\mathrm{E}$ and between $9480000 \mathrm{~m} \mathrm{~N}$ and $9500000 \mathrm{~m} \mathrm{~N}$, Zone 37M, covering about 34,000ha. The altitude ranges from 480 to $2271 \mathrm{~m}$ above sea level (Figure1). The area has a bimodal rainfall pattern with an annual total ranging from 600 to $1,200 \mathrm{~mm}$. The study area is characterized by a mixed farming system. Rainfed agriculture is the most important land use followed by irrigated agriculture, livestock keeping and off farm activities including petty cash and carpentry (Msita et al., 2010). Other land uses include natural forestry, plantation forests and utility woodlots (Kaoneka \& Solberg, 1994). Study sites were selected to reflect a geographic gradient in the frequency of plague incidence, based on results from previous research on rodents, fleas and plague casualties conducted in the area (Njunwa et al., 1989; Kilonzo et al., 1997; Davis et al., 2006; Kamugisha et al., 2007; Laudisoit et al., 2007, 2009a,b; Neerinckx et al., 2010).

In selecting the study sites four criteria were used for detailed studies which include: (a) The incidence of plague as recorded for the period from 1986 to 2004, which in former studies allowed to subdivide the study area into three major landscapes of high (villages where plague incidence rates on average were 4.17-10.46 cases/1000 inhabitants), medium (1.91-4.17 cases/1000 inhabitants) and low (0.02-1.91 cases/1000 inhabitants) incidence; (b) Land use and human activity diversity; (c) Landform characteristics (plain, escarpment, plateau dissected at different levels and valleys); and (d) Climatic conditions. On the basis of these criteria, three landscapes were selected: (i) The Shume landscape (high plague incidence) - dissected upper part of the escarpment-edge of the plateau. The area is located in the cold dry zone (average temperature ranges between $15-19^{\circ} \mathrm{C}$, elevation $953-2040 \mathrm{~m}$ and annual rainfall of $500-800 \mathrm{~mm}$ ); the irregularly shaped $500 \mathrm{~m}$ deep escarpment has slopes up to 68 degrees and rock outcrops (Pfeiffer, 1990); (ii) The Lukozi landscape (medium plague incidence) - characterised by strongly dissected plateau, with broad ridge crest/summits and deep soils. The area is also situated in the cold dry zone. The average annual temperature ranges between $18-23^{\circ} \mathrm{C}$ with an average annual 
rainfall of 1,00omm and elevation of 1,750-2,205m (Pfeiffer, 1990; Kaoneka \& Solberg, 1997); (iii) The Mwangoi landscape (low plague incidence) is characterised by strongly dissected sunken part of the plateau. The climate in this area is hot and dry (average temperature $22^{\circ} \mathrm{C}$ ), annual rainfall of 500-800 mm with an elevation of 1346-2002m (Pfeiffer, 1990)).

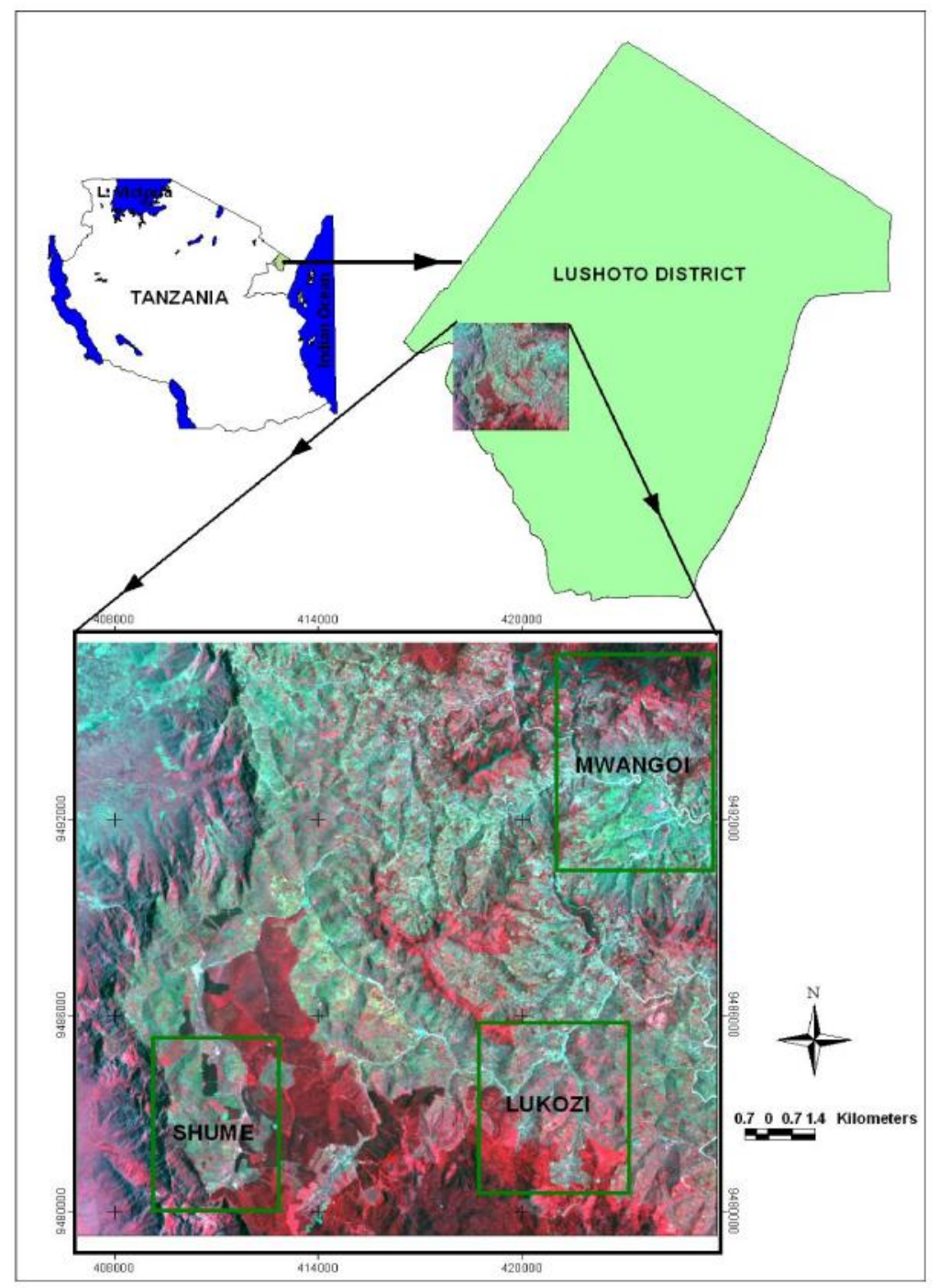

Figure 1: Location of study area: The Shume, Lukozi and Mwangoi landscapes

\section{Sampling procedure}

A total of 72 observation sites (quadrats) 100x100m were established. Twenty four quadrats were established per sample area (landscape). Stratified random sampling procedure based on broad land cover types and topography was used to locate the quadrats in each sample area. Decision on the number of observation sites considered representative sample size, time and human resources availability. At each observation site, data on land use including farm practices and management, small mammals and fleas combed out from small mammals were collected. Data collection was done in both wet (April-June 2012) and dry (August-October 2012) seasons. 


\section{Land use data}

At each of the observation sites various visible indicators of land use were georeferenced and mapped. Two major categories namely, land management practices and crop types were classified. The land management practices were identified by characteristic land cover patterns as seen in the field. For example a rectangular Guatemala/elephant grass strips cover was identified as miraba (an indigenous land management practice with grass strips surrounding crop fields). Thus in this category five land use management types were mapped which include miraba, terraces, other hedge-like structures, tree stumps (dead and live) and fallow. "Other hedge-like structures" included crop fields demarcating grass/shrub strips, and hedges along footpath/roads and around houses. Fallow was composed of such land cover type as bushed grassland, bushes, shrubs, unattended banana bushes, and inter-seasonal weedy/shrub fallow, or a mixture of these.

Crop types and other elements were also identified by characteristic land cover patterns as seen in the field. For a field with a mixture of crops, each crop type was differentiated from other crop or physical features. In this group a total of 15 categories were mapped: maize, cassava, beans, potato, sugarcane, vegetables, settlement, Guatemala grass fields, tilled land, woodlot, rock outcrop, natural forest, plantation forest (monocrop), plantation forest (with annual crop farming going on or recently stopped) and other land uses. The "vegetables" category had a mixture of vegetables commonly grown in Lushoto (Kaoneka \& Solberg, 1997). "Other land uses" category had a mixture of crops which were scant within quadrats (not one of the above listed crops). "Woodlots" had one or mixture of such land cover types as eucalyptus, grevillea, black wattle and pine woodlots. Each of the categories natural forest, plantation forest monocrop and plantation forest with farming activities were treated as single use in their respective observation sites.

\section{Data on small mammals}

Small mammals were captured mainly using Sherman LFA live traps $(7.5 \times 9.0 \times 23 \mathrm{~cm}$; HB Sherman Traps, Tallahassee, USA) baited with peanut butter and maize flour. A total of 49 Sherman live traps spaced $10 \mathrm{~m}$ apart were set in grids per trapping (observation) site for each trapping session. For the sites in natural forests, additionally two wire cages were used to capture somewhat bigger mammals like squirrels. Each trapping session lasted 3 nights. Each trap was inspected every morning and traps with captured animals were replaced by empty traps. Each captured animal was weighed; its sex identified and morphological measurements (length of body, tail, ear and hind foot) recorded and identified. For small mammals species that could not be identified to species level due to lack of morphological differences that were detectable in the field, individuals were identified to genus level (Eisen et al., 2012).

\section{Data analysis}

Data collected in the dry and wet seasons were compiled and descriptive statistical analysis and one-way analysis of variance (ANOVA) were carried out. Data included: Land use variables for Shume, Lukozi and Mwangoi landscapes; small mammals (genus/species name), trap success and overall fleas index per landscape. The trap success was calculated as number of animals trapped times 100 divided by the product of number of traps used and duration in terms of nights during which the trap was set (Laudisoit et al., 2009a). Overall flea index was calculated as the total number of fleas collected in a landscape per total number of captured small mammals in that landscape (Laudisoit et al., 2009a).

Prior to ANOVA, data was checked for normality and homogeneity (Zuur et al., 2010). Whenever normality was not fulfilled, data were $\log _{10}(x+3 / 8)$ transformed to achieve normal distributions (Axelsson et al., 2011; SAS Resource on the web, 2012). All statistical analyses were done using MS Excel and Minitab 14 software at the 95\% confidence level. A one-way ANOVA of trap success among land use types was carried out on aggregated land uses data. For example 
wherever the observation site was dominated by both annual and perennial crops, the aggregated land use type for that particular observation site was classified as 'Mixed annual perennial crops' and wherever the observation site was composed of natural forest only the aggregated land use type became 'Natural forest'. A total of seven groups of aggregated land use (Plantation forest with farming, Natural forest, Fallow, Mixed annual crops, Mixed annual perennial crops, Plantation forest monocrop, Woodlot) were classified. Trap success was treated as dependent variable and aggregated land use was treated as independent variable.

Boosted Regression Trees (BRT) modelling technique was used to establish the relationships between small mammals' abundance (trap success) and individual land use variables. The individual land use variables used in BRT model are the originally sampled variables before aggregation. Boosted Regression Trees were constructed in $\mathrm{R}$ statistical program version 2.6.2 (R Development Core Team, 2006) using custom code (Elith et al., 2008). Analyses were based on a Gaussian distribution. The 10-fold cross-validation (CV) was used for model development and validation, with the benefit of still using the full data set to fit the final model. Models were fitted using the gbm.step function (aimed at minimising squared error), with most effective settings for learning rate (0.01-0.000001) and bag fraction $(0.5-0.75)$ as found by repeated trial-and-error.

Tree complexity, i.e. the number of nodes in a tree, was set to 3 , according to recommendations by Elith et al. (2008) for small datasets. The measure of model performance was cv deviance and standard error (Elith et al., 2008; Williams et al., 2010). The combination of learning rate and bag fraction settings with the lowest $c v$ deviance and standard error was the one selected to produce the final BRT model (Williams et al., 2010). Also during data exploration all predictor variables were tested for ecologically acceptable level of collinearity (i.e. individual variance inflation factor (VIF) of <5) between predictor variables (Zuur et al., 2010; Aertsen et al., 2012). Partial dependency plots were used for interpretation and to quantify the relationship between each predictor variable and the trap success (Elith et al., 2008). The unit of measurement for Miraba, Other hedge-like structures and Terraces predictor variables was length ( $m$ ) whereas Tree stumps were counted (number). The rest of land uses variables were measured as proportions of coverage (\%) of each land use within sampled $100 \times 100$ m quadrat area.

\section{Ethical considerations}

This study received approval from Directorate of Research and Post-Graduate Studies of Sokoine University of Agriculture, Tanzania and Flemish Inter-University Council (VLIR-UOS) of Belgium.

\section{Results}

\section{Influence of aggregated land use types on small mammal abundance}

The trap success among aggregated land use types indicated significant variation at $p \leq 0.05$. The highest trap success was found in Plantation forest with farming followed by Natural forest and Fallow whereas the lowest was recorded in Woodlot (Table 1).

Table 1: Influence of aggregated land use types on small mammal abundance

\begin{tabular}{lll}
\hline Season & Land use & Mean Trap success (\%) \\
\hline Dry season & Plantation forest with farming & 10.33 \\
& Natural forest & 8.16 \\
& Fallow & 6.43 \\
& Mixed annual crop & 4.46 \\
& Mixed annual perennial crop & 3.63 \\
& Plantation forest monocrop & 1.27 \\
\hline Wet season & Woodlot & 1.99 \\
& Natural forest & 8.33 \\
& Plantation forest with farming & 8.18
\end{tabular}




$\begin{array}{ll}\text { Fallow } & 4.45 \\ \text { Mixed annual crops } & 4.11 \\ \text { Mixed annual perennial crops } & 2.69 \\ \text { Plantation forest monocrop } & 1.57 \\ \text { Woodlot } & 0.58\end{array}$

\section{Influence of individual land use variables on small mammal abundance as demonstrated by BRT} model

Seven land use variables (predictor variables) were selected by the BRT model to have influence (to be important) on the observed spatial pattern of trap success (small mammal abundance) during the dry season (Figure 2). All seven predictor variables had the ecologically acceptable level of individual variance inflation factor $(\mathrm{VIF}<5)$. Miraba was the most important predictor with contribution of more than a third of the total (40.5\%) and a strong positive effect. The presence of at least $25 \mathrm{~m}$ of miraba was enough for trap success increase. Fallow was the second important predictor with contribution of $22.9 \%$ and a strong positive effect. A threshold value of $20 \%$ fallow appeared to be an important condition for an increase of trap success. The third important predictor was other hedge-like structures (13.1\% contribution) with immediate strong negative effect followed by weak positive effect with the higher and lower values respectively lying around zero. Tillage had contribution of only $8 \%$ and a weak then strong negative effect. The presence of at least $5 \%$ of tilled land appeared to be an important condition for a decrease of trap success. Other predictors had relatively weak influence and small contributions.
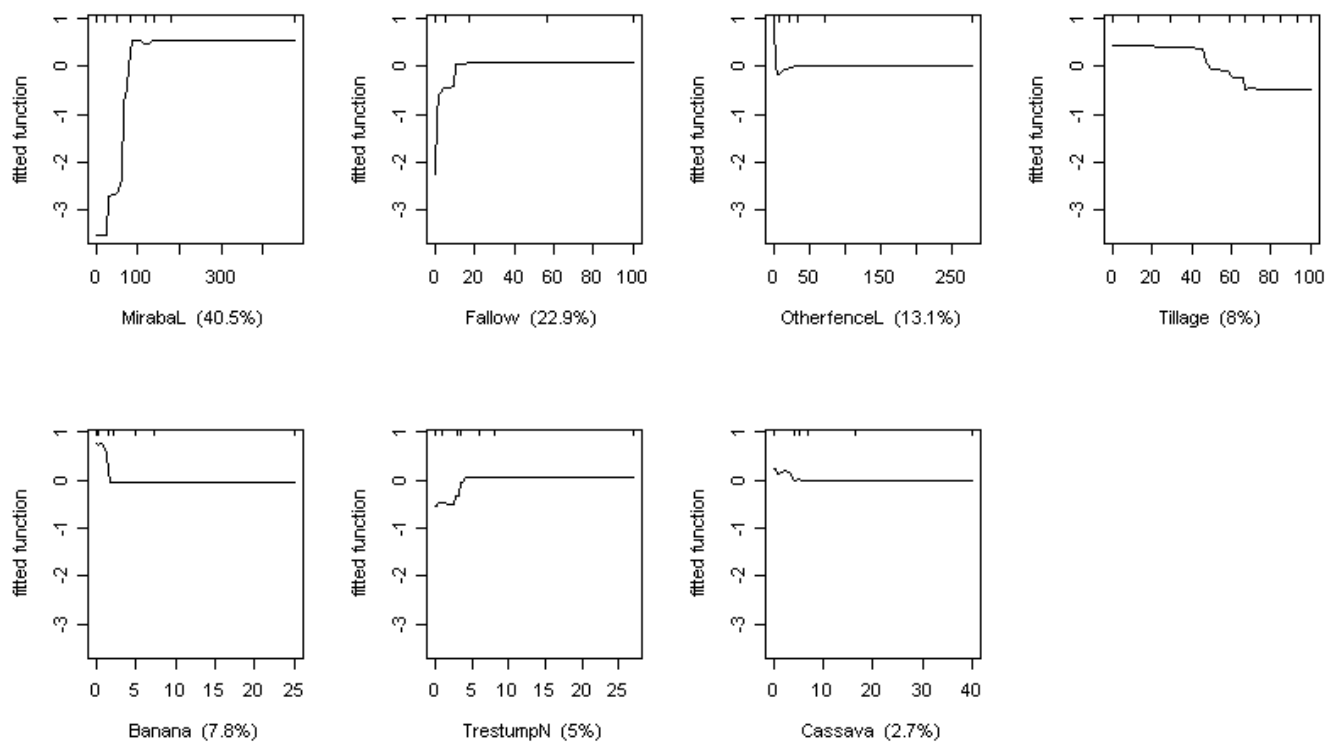

Figure 2: Partial dependence plots showing the effect of land use on spatial pattern of trap success during dry season. The relative contribution of each predictor is reported between brackets. CV deviance $=21.6$, standard error $=5.943$, number of trees $=3250$.

Key: TrestumpN= Tree stump, MirabaL=Miraba, OtherfenceL= Other hedge-like structures, $\mathrm{CV}=\mathrm{cross}$ validation

Five land use variables (predictor variables) were selected by the BRT model to have influence (to be important) on the observed spatial pattern of small mammals in the wet season (Figure 3). All five predictor variables had the ecologically acceptable level of individual variance inflation factor $(\mathrm{VIF}<5)$. Potato was the most important predictor with contribution of half of the total $(51.8 \%)$ and immediately showed a strong positive effect; the lower limit of the proportion of potatoes 
being only slightly greater than $0 \%$. This implies that having just few potatoes in a field was enough to trigger off increased abundance of small mammals. Miraba and maize with contributions of $14 \%$ and $7.8 \%$, respectively had weak positive influence. Other hedge-like structures (10.8\% contribution) had immediate strong negative influence between 0 and $20 \mathrm{~m}$ length. Tree stumps had a contribution of $15.5 \%$ but with a weak effect.
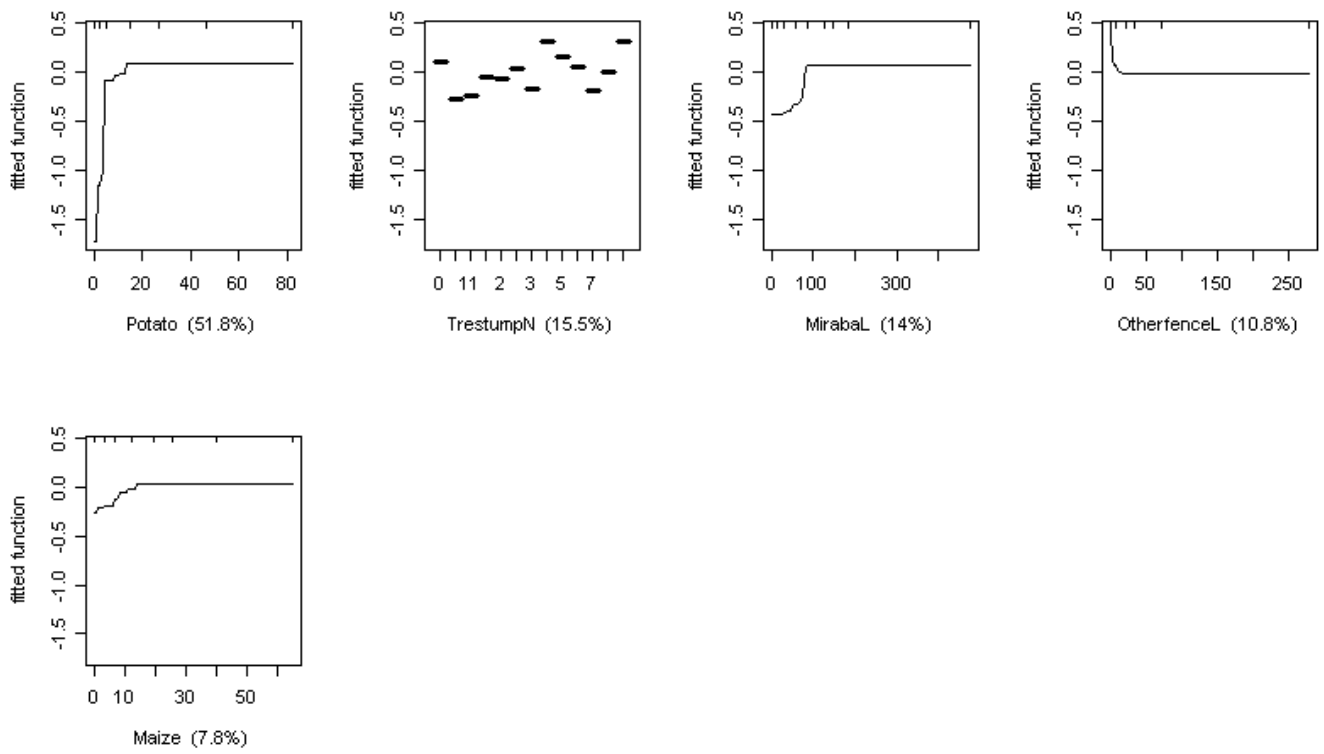

Figure 3: Partial dependence plots showing the effect of land use on spatial pattern of trap success during wet season. The relative contribution of each predictor is reported between brackets. CV deviance=12.911, standard error=2.633, number of trees $=1200$.

Key: TrestumpN= Tree stump, MirabaL=Miraba, OtherfenceL= Other hedge-like structures, $\mathrm{CV}=\mathrm{cross}$ validation

Table 2: Distribution of small mammals and fleas by season collected in the three landscapes

\begin{tabular}{llll|lll}
\hline Season & \multicolumn{2}{l}{ Dry season } & \multicolumn{5}{l}{ Wet season } \\
\hline Landscape & Shume & Lukozi & Mwangoi & Shume & Lukozi & Mwangoi \\
\hline $\begin{array}{llllll}\text { Small } \\
\text { (Genus/Species) }\end{array}$ & & & & & & \\
\hline Mastomys natalensis & $166(62.6 \%)$ & $140(60.3 \%)$ & $26(32.9 \%)$ & $111(47.4 \%)$ & $73(37.8 \%)$ & $34(36.6 \%)$ \\
Lophuromys sp. & $30(11.3 \%)$ & $19(8.2 \%)$ & $5(6.3 \%)$ & $51(21.8 \%)$ & $24(12.4 \%)$ & $6(6.5 \%)$ \\
Praomys sp. & $9(3.4 \%)$ & $36(15.5 \%)$ & $14(17.7 \%)$ & $11(4.7 \%)$ & $54(28.0 \%)$ & $33(35.5 \%)$ \\
Arvicanthis sp. & $14(5.3 \%)$ & $4(1.7 \%)$ & $3(3.8 \%)$ & $9(3.8 \%)$ & $5(2.6 \%)$ & $0(0.0 \%)$ \\
Crocidura sp. & $9(3.4 \%)$ & $0(0.0 \%)$ & $1(1.3 \%)$ & $12(5.1 \%)$ & $14(7.3 \%)$ & $5(5.4 \%)$ \\
Mus sp. & $13(4.9 \%)$ & $19(8.2 \%)$ & $10(12.7 \%)$ & $10(4.3 \%)$ & $10(5.2 \%)$ & $1(1.1 \%)$ \\
Grammomys sp. & $13(4.9 \%)$ & $11(4.7 \%)$ & $8(10.1 \%)$ & $16(6.8 \%)$ & $9(4.7 \%)$ & $12(12.9 \%)$ \\
Aethomys sp. & $6(2.3 \%)$ & $0(0.0 \%)$ & $9(11.4 \%)$ & $10(4.3 \%)$ & $0(0.0 \%)$ & $0(0.0 \%)$ \\
Lemniscomys sp. & $3(1.1 \%)$ & $1(0.4 \%)$ & $1(1.3 \%)$ & $0(0.0 \%)$ & $0(0.0 \%)$ & $0(0.0 \%)$ \\
Otomys sp. & $2(0.8 \%)$ & $1(0.4 \%)$ & $0(0.0 \%)$ & $1(0.4 \%)$ & $21.0 \%)$ & $1(1.1 \%)$ \\
C.gambianus & $0(0.0 \%)$ & $1(0.4 \%)$ & $0(0.0 \%)$ & $0(0.0 \%)$ & $2(1.0 \%)$ & $0(0.0 \%)$ \\
Beamys sp. & $0(0.0 \%)$ & $0(0.0 \%)$ & $1(1.3 \%)$ & $0(0.0 \%)$ & $0(0.0 \%)$ & $0(0.0 \%)$ \\
Rattus rattus & $0(0.0 \%)$ & $0(0.0 \%)$ & $0(0.0 \%)$ & $3(1.3 \%)$ & $0(0.0 \%)$ & $0(0.0 \%)$ \\
Paraxerus sp. & $0(0.0 \%)$ & $0(0.0 \%)$ & $1(1.3 \%)$ & $0(0.0 \%)$ & $0(0.0 \%)$ & $1(1.1 \%)$ \\
Total small mammals & 265 & 232 & 79 & 234 & 193 & 93 \\
Total fleas & 358 & 180 & 137 & 179 & 124 & 67 \\
Flea index & 1.4 & 0.8 & 1.7 & 0.8 & 0.6 & 0.7 \\
\hline
\end{tabular}




\section{Abundance and diversity of small mammals in different landscapes with historical plague incidence}

Mastomys natalensis, Lophuromys sp. and Praomys sp. were the dominant species in both wet and dry seasons and make up a total of 842 animals which is $76.8 \%$ of the total catch (Table 2). Shume landscape had many $M$. natalensis and Lophuromys sp. than the rest of the landscapes in both seasons. Aethomys sp. were captured only in Shume and Mwangoi landscapes. Other captured small mammals were Rattus rattus in Shume landscape only and Paraxerus sp. and Beamys sp. in Mwangoi landscape only. Figure 4 shows the mean trap success per trapping (observation) site. The results show that in both seasons, Shume landscape had more small mammals per observation site than Lukozi and Mwangoi. Seasonal difference is also clear whereby dry season had higher values compared to wet season for Shume and Lukozi whereas in Mwangoi it was the opposite. The overall flea indices for all three landscapes ranged from 0.6 to 1.7 .

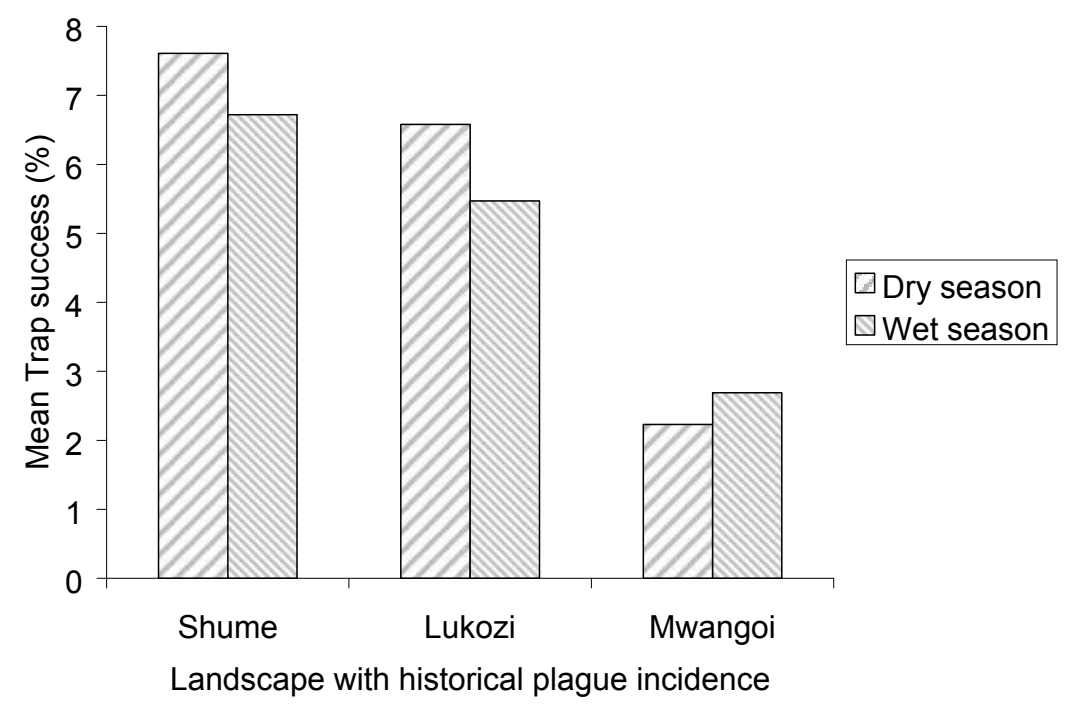

Figure 4: Mean trap success per sampling site in different landscapes in dry and wet seasons

\section{Discussion}

Variation in distribution of small mammals as influenced by land use types as observed in the current study is consistent with previous observations in the area (Laudisoit et al., 2009a). These variations may be attributed to the fact that, Plantation forest with crop farming provides both shelter and food resources (Tews et al., 2004). Fallow land is mainly surrounded by agricultural fields - a combination that provides shelter, breeding sites and supplementary food for rodents (Mwanjabe, 1993). Natural forest also provides food, water and shelter for small mammals. Generally, the results confirm findings from previous studies that small mammal abundance and distribution is critically associated with availability of food and shelter (Cooney et al., 1982). Results with the BRT model suggest miraba to be the most important predictor of small mammal abundance. Miraba is a unique indigenous soil erosion control practice in the Usambara Mountains (Msita et al., 2011). Miraba filter sediments from the runoff but the grasses grown in miraba construction may be used as animal fodder which is an added advantage. Miraba have many attributes as habitat for small mammals. They provide better locations for rodent burrows which do not easily get flooded with water during rainy season as well as shelter against predators (Kamugisha et al., 2007; Msita et al., 2011).

Fallows which were identified and discriminated as being composed of such vegetation types as bushed grassland, bushes, shrubs, unattended banana bushes, and inter-seasonal weeds and shrub fallow had positive influence on small mammal abundance during the dry season. 
These vegetation types were previously found to be associated with rodents in the study area (Makundi et al., 2007; Laudisoit et al., 2009a). Indeed, these vegetation types not only provide nesting sites and diverse food sources, but also offer an effective shelter for ground dwelling small mammals from carnivores and avian predators (Tews et al., 2004), and, hence, there is lower predation risk in these closed habitats (Laudisoit et al., 2009a). Fallow land matrices thus serve as refuges for rodents that infest crop fields (Makundi et al., 2007; Mulungu et al., 2011). These findings shed light on the possible link between these two land management practices, i.e. miraba and fallow and plague infection risk during epizootic periods. This is because, previous studies in the Lushoto and Mbulu foci in Tanzania show that plague outbreak has been occurring after rodent increase (outbreak) followed by rodent mortality (Kilonzo et al., 2005; Makundi et al., 2008).

Land tillage, which takes place during the dry season, had a strong negative effect on trap success. Tillage of land could have resulted in the destruction of mounds, removal of vegetation and destruction of nest sites some of which comprise food sources and shelter for the rodents. It may also be associated with alteration of soil micro-environment including exposure of small mammals to predators. Similar findings have been reported by Massawe et al. (2006). These observations are of practical significance to the local communities with regard to keeping their surroundings clean and reducing the duration of fallow periods although the latter may be at variance with acceptable conservation practices. This could curtail rodent build-up and hence minimize risk of contracting plague.

During the wet season, both potato and maize crops appeared to have a direct and positive influence on small mammal abundance. This could be attributed to the fact that the most critical factors that have been found to influence rodent distribution are thought to be related to the availability of food and shelter (Cooney et al., 1982). Interviews with key informants revealed that maize and potato were among the crops reported to be highly preferred by rodents in the study area. Similar findings have been reported by Mulungu et al. (2011).

The three dominant species of small mammals (Mastomys natalensis, Lophuromys sp. and Praomys sp.) observed in this study have been previously reported to be involved in the plague transmission in the study area (Kilonzo \& Mhina, 1982; Makundi et al., 2007, 2008). The overall flea index (0.6 - 1.7) which was associated with the captured small mammals in this study, further indicates the potential risk of transmitting the disease from small mammals to humans during epizootics (Kilonzo et al., 1992; Eisen et al., 2006; Laudisoit, 2009). The general trend of values of absolute number and mean trap success of small mammals was Shume>Lukozi>Mwangoi. This could be explained by land use pattern differences where Shume has more plantation forest with farming, fallow lands and rock outcrops which seem to attract more rodents (Laudisoit et al., 2009a; Mulungu et al., 2011). The other reasons might be related to topography which also varies in terms of providing food, water and shelter. In other words, Shume appears to be a natural habitat for small mammals.

The current study has demonstrated that small mammal abundance and distribution is strongly influenced by the specific land use types. These results suggest that land management practices including tillage of land and crop types and the associated human activities should be included in the general scheme of plague maintenance and transmission mechanisms. Future efforts to predict and map spatial and temporal human plague infection risk at farm scale should consider the role played by land use on small mammal abundance and distribution. These findings therefore, make a significant contribution towards efforts in the control of plague risk factors in space and time. Small mammal presence in different land use types can influence abundance of certain flea species. However, since rodent fleas are ectoparasites which tend to inhabit both rodents (hosts) and off-host environment, additional investigation on how land use practices affect microclimate conditions for fleas living on and momentarily off-host is vital. 


\section{Acknowledgements}

This work was supported by the Sokoine University of Agriculture - Flemish Interuniversity Council Own Initiative Project - 'Landscape-Ecological Clarification of Bubonic Plague Distribution and Outbreaks in the Western Usambara Mountains, Tanzania' (Acronym: LEPUS), funded by the Flemish Interuniversity Council, Belgium. The authors greatly appreciate the cooperation of many people including farmers in the study area, staff of Lushoto District Council and Sebastian Kolowa Memorial University.

\section{References}

Aertsen, W., Kint, V., Vos Bruno De, Deckers, J., Van Orshoven, J. \& Muys, B. (2012) Predicting forest site productivity in temperate lowland from forest floor, soil and litterfall characteristics using boosted regression trees. Plant Soil 354, 157-172.

Axelsson, E.P., Hjältén, J., LeRoy, C.J., Thomas, G., Whitham, T.G., Julkunen-Tiitto, R. \& Wennström, A. (2011) Leaf litter from insect-resistant transgenic trees causes changes in aquatic insect community composition. Journal of Applied Ecology 48, 1472-1479.

Blaum, N., Rossmanith, E. \& Jeltsch, F. (2007) Land use affects rodent communities in Kalahari savannah rangelands. African Journal of Ecology 45, 189-195.

Davis, S., Makundi, R.H., Machang'u R.S. \& Leirs, H. (2006) Demographic and spatio-temporal variation in human plague at a persistent focus in Tanzania. Acta Tropica 100, 133-141.

Eisen, R.J., Bearden, S.W., Wilder, A.P, Montenieri, J.A., Antolin, M.F. \& Gage, K.L. (2006) Early phase transmission of Yersinia pestis by unblocked fleas as a mechanism explaining rapidly spreading plague epizootics. Proceedings of the National Academy of Science of the United States 103, 15380-15385.

Eisen, R.J., Borchert, J.N., Mpanga, J.T., Atiku, L.A., MacMillan, K., Boegler, K.A., Montenieri, J.A., Monaghan, A. \& Gage, K.L. (2012) Flea diversity as an element for persistence of plague bacteria in an East African Plague Focus. PLoS One 7(4), e35598.

Elith, J., Leathwick, J.R. \& Hastie, T. (2008) A working guide to boosted regression trees. Animal Ecology 77, 802-813.

Gage, K.L. \& Kosoy, M.Y. (2005) Natural history of plague: perspectives from more than a century of research. Annual Review of Entomology 50, 505-528.

Isabirye-Basuta, G.M. \& Kasenene, J.M. (1987) Small rodent populations in selectively felled and mature forest tracts of Kibale Forest, Uganda. Biotropica 19, 260-266.

Kamugisha, M.L., Gesase, S., Minja, D., Mgema, S., Mlwilo, T.D., Mayala, B.K., Msigwa, S., Massaga, J.J. \& Lemnge, M.M. (2007) Pattern and spatial distribution of plague in Lushoto, north-eastern Tanzania. Tanzania Health Research Bulletin 9, 12-18.

Kaoneka, A.R.S. \& Solberg, B. (1994) Forestry related land use in West Usambara mountains, Tanzania. Agriculture, Ecosystems and Environment 49, 207-215.

Kaoneka, A.R.S. \& Solberg, B. (1997) Analysis of deforestation and economically sustainable farming systems under pressure of population growth and income constraints at the village level in Tanzania. Agriculture, Ecosystem and Environment 62, 59-70.

Kilonzo, B, Mhina, J, Sabuni, C. \& Mgode, G. (2005) The role of rodents and small carnivores in plague endemicity in Tanzania. Belgian Journal of Zoology 135, 119-125.

Kilonzo, B.S. \& Mhina, J.I. (1982) The first outbreak of human plague in Lushoto district, northeast Tanzania. Transactions of the Royal Society of Tropical Medicine and Hygiene 76, 172177.

Kilonzo, B.S., Mvena, Z.S.K., Machang'u, R.S. \& Mbise, T.J. (1997) Preliminary observations on factors responsible for long persistence and continued outbreaks of plague in Lushoto district, Tanzania. Acta Tropica 68, 215-227. 
Laudisoit, A., Leirs, H., Makundi, R.H. \& Krasnov, B. (2009a) Seasonal and habitat dependence of fleas parasitic on small mammals in Tanzania. Integrative Zoology 4, 196-212.

Laudisoit, A., Leirs, H., Makundi, R.H., Van Dongen, S., Davis, S., Neerinckx, S., Deckers, J. \& Libois, R. (2007) Plague and the human flea, Tanzania. Emerging Infectious Diseases 13, 687693.

Laudisoit, A., Neerinckx, S., Makundi, R.H., Leirs, H. \& Krasnov, B. (2009b) Are local plague endemicity and ecological characteristics of vectors and reservoirs related? A case study in north-east Tanzania. Current Zoology 55, 199-211.

Laudisoit, A. (2009) Diversity, ecology and status of potential hosts and vectors of the plague bacillus Yersinia pestis: Contribution to the Plague Epidemiology in an Endemic Plague Focus: The Lushoto District, Tanzania. PhD Thesis, Universiteit Antwerpen, Belgium. 259pp.

Linard, C., Lamarque, P., Heyman, P., Ducofftre, G., Luyasu, V., Tersago, K., Vanwambeke, O.S. \& Lambin, E.F. (2007) Determinants of the geographic distribution of Puumala virus and Lyme borreliosis infection in Belgium. International Journal of Health Geographics 6, 15.

Makundi, R.H., Kilonzo, B.S. \& Massawe, A.W. (2003) Interaction between rodent species in agroforestry habitats in the western Usambara Mountains, north-eastern Tanzania, and its potential for plague transmission to humans. In: G.R. Sigleton, L.A. Hinds, C.J. Crebs \& D.M. Pratt (eds): Rats, Mice and People: Rodent Biology and Management. Australian Centre for international Agricultural Research, Canberra, pp. 20-24.

Makundi, R.H., Massawe, A. \& Mulungu, L. (2007) Reproduction and population dynamics of Mastomys natalensis Smith, 1834 in an agricultural landscape in the Western Usambara Mountains, Tanzania. Integrative Zoology 2, 233-238.

Makundi, R.H., Massawe, A.P., Mulungu, L.S., Katakweba, A., Mbise, T.J. \& Mgode, G. (2008) Potential mammalian reservoirs in a bubonic plague outbreak focus in Mbulu District, northern Tanzania, in 2007. Mammalia 72, 253-257.

Massawe, A., Rwamgira, W., Leirs, H., Makundi, R.H. \& Mulungu, L.(2006) Do farming practices influence population dynamics of rodents? A case study of the multimammate field rats, Mastomys natalensins, in Tanzania. African Journal of Ecology 45, 293-301.

Msita, H.B., Kimaro, D.N., Kihupi, N.I., Dondyene, S., Msanya, B.M., Mtakwa, P.W., Poesen, J. \& Deckers, J. (2011) Evolution of Miraba: an indigenous soil erosion control technology in the Western Usambara Mountains, Tanzania. Paper presented to the International congress on Integrated Water-Resources Management in Tropical and Subtropical Dry Lands held at Mekelle, Ethiopia from 19-26 September 2011.

Msita, H.B., Kimaro, D.N., Deckers, J. \& Poesen, J. (2010) Identification and Assessment of Indigenous Soil Erosion Control Measures in the Usambara Mountains, Tanzania. Chapter 3 in Earl T. Nardal (Editor). No-Till Farming: Effects of Soil, Pros and Cons and Potential. Agriculture Issues and Policies Series. ISBN: 978-1-60741-402-5. Nova Science Publishers Inc, New York: 49-74.

Mulungu, L.S, Ngowo, V.D., Makundi, R.H., Massawe, A.W. \& Leirs, H. (2010) Winning the Fight against Rodent Pests: Recent Developments in Tanzania. Journal of Biological Sciences B 10, 333-340.

Mulungu, L.S., Mahlaba, T.A., Massawe, A.W., Kennis, J., Crauwels, D., Eiseb, S., Monadjem, A., Makundi, R.H., Katakweba, A.A.S., Leirs, H. \& Belmain, S.R. (2011) Dietary differences of the multimammate mouse, Mastomys natalensins (Smith, 1834), across different habitats and seasons in Tanzania and Swaziland. Wildlife Research 38, 640-646.

Mwanjabe, P.S. (1993) The role of weeds on population dynamics of Mastomys natalensis in Chunya (Lake Rukwa) valley. In: Economic Importance and Control of Rodents in Tanzania. In: R.S. Machang'u (ed.), pp. 34-42. Sokoine University of Agriculture, Morogoro. 
Neerinckx, S., Peterson, A.T., Gulinck, H., Deckers, J., Kimaro, D. \& Leirs, H. (2010) Predicting potential risk areas of human plague for the Western Usambara Mountains, Lushoto District Tanzania. American Journal of Tropical Medicine and Hygiene 82, 492-500.

Njunwa, K.J., Mwaiko, G.L., Kilonzo, B.S. \& Mhina, J.I. (1989) Seasonal patterns of rodents, fleas and plague status in the Western Usambara Mountains, Tanzania. Medical and Veterinary Entomology 3, 17-22.

Williams, G.J., Aeby G.S., Cowie, R.O.M. \& Davy, S.K. (2010) Predictive Modelling of Coral Disease Distribution within a Reef System. PLoS ONE 5(2), eg264.

R Development Core Team (2006) R: A Language and Environment for Statistical Computing. R Foundation for Statistical Computing, Vienna. [www.ipensieri] Accessed on 06.09.2011.

SAS Resource on the web (2012) On biostatistics and clinical trials. [http://onbiostatistics.blogspot.com/2012_05_01_archive.html]. Accessed on 26.03.2014.

Tews, J., Blaum, N. \& Jeltsch, F. (2004) Structural and animal species diversity in arid and semiarid savannas of the southern Kalahari. Annals of Arid Zone 42, 1-43.

Zuur, A.F., leno, E.N. \& Elphic, C.S. (2010) A Protocol for data exploration to avoid common statistical problems. Methods in Ecology and Evolution 1, 3-14. 